\title{
Pemanfaatan Buku Cerita Bergambar Digital Berbasis Audio Visual terhadap Stimulasi Kemampuan Empati Anak Usia Dini
}

\section{Ni Ketut Sumiati1 ${ }^{*}$, Luh Ayu Tirtayani2}

1,2 Jurusan Pendidikan Dasar, Universitas Pendidikan Ganesha, Singaraja, Indonesia

\section{ART I CLE IN F O}

Article history:

Received 27 Mei 2021

Revised 28 Mei 2021

Accepted 01 Juli 2021

Available online 25 Agustus 2021

Kata Kunci:

Buku Cerita, Audio Visual, Empati

Keywords:

Story Books, Audio Visual Media, Emphaty

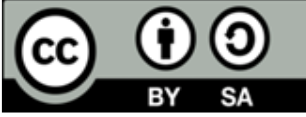

This is an open access article under the CC BY-SA license.

Copyright (ㅇ 2021 by Author. Published by Universitas Pendidikan Ganesha.

\section{ABSTRACT}

\begin{abstract}
A B S T R A K
Mengingat masih rendahnya kemampuan empati pada anak, sedangkan guru belum dapat memberikan stimulus melalui media pembelajaran yang lebih efektif serta bervariasi. Penelitian ini bertujuan untuk menentukan validitas buku cerita bergambar digital berbasis audio visual dalam upaya untuk menstimulasi kemampuan empati anak kelompok B. Jenis penelitian ini adalah penelitian pengembangan dengan menggunakan model ADDIE (Analyze, Design, Development, Implementation, Evaluation). Subjek penelitian ini ada tiga yaitu ahli isi materi, ahli desain pembelajaran, ahli media pembelajaran, dan tiga orang anak kelompok B. Metode pengumpulan data pada penelitian ini yaitu metode observasi, wawancara dan angket. Instrumen penelitian yang digunakan berupa angket. Data dianalisis menggunakan analisis deskriptif kuantitatif dan analisis deskriptif kualitatif. Hasil penelitian ini menunjukkan proses pengembangan aplikasi buku cerita bergambar digital berbasis audio visual melalui tahap analisis, perancangan, pengembangan, dan evaluasi. Hasil uji validitas aplikasi buku cerita bergambar anak oleh ahli desain pembelajaran memperoleh persentase skor $85 \%$ dengan kualifikasi baik. Hasil uji validitas aplikasi buku cerita bergambar anak oleh ahli media pembelajaran memperoleh persentase skor $85 \%$ dengan kualifikasi baik. Hasil uji validitas aplikasi buku cerita bergambar anak oleh ahli materi memperoleh persentase skor $85 \%$ dengan kualifikasi baik. Hasil uji validitas aplikasi buku cerita bergambar anak oleh subjek uji coba perorangan memperoleh persentase skor $97 \%$ dengan kualifikasi sangat baik.
\end{abstract}

\begin{abstract}
Given the low ability of empathy in children, while teachers have not been able to provide a stimulus through more effective and varied learning media. This study aims to determine the validity of audiovisual-based digital illustrated storybooks in an effort to stimulate the empathy skills of group $B$ children. This type of research is development research using the ADDIE model (Analyze, Design, Development, Implementation, Evaluation). The subjects of this study were content experts, instructional design experts, instructional media experts, and three children in group $B$. The data collection methods in this study were observation, interviews and questionnaires. The research instrument used was a questionnaire. Data were analyzed using quantitative descriptive analysis and qualitative descriptive analysis. The results of this study indicate the process of developing an audiovisual-based digital picture story book application through the stages of analysis, design, development, and evaluation. The results of the validity test of the children's picture story book application by learning design experts obtained a percentage score of $85 \%$ with good qualifications. The results of the validity test of the children's picture story book application by learning media experts obtained a percentage score of $85 \%$ with good qualifications. The results of the validity test of the children's picture story book application by material experts obtained a percentage score of $85 \%$ with good qualifications. The results of the validity test of the children's picture story book application by individual test subjects obtained a percentage score of $97 \%$ with very good qualifications.
\end{abstract}




\section{PENDAHULUAN}

Perkembangan teknologi yang terjadi saat ini sangat berpengaruh terhadap kehidupan khususnya dalam dunia pendidikan. Perkembangan era globalisasi yang sangat pesat menuntut dunia pendidikan untuk menyesuaikan perkembangan teknologi informasi terhadap usaha dalam meningkatkan kualitas pendidikan (Kharisma \& Arvianto, 2019; Kumalasani, 2018). Teknologi informasi dapat digunakan untuk mengakses ilmu pengetahuan dengan mudah dan cepat, maka dengan adanya teknologi informasi dalam pendidikan dapat menghasilkan sumber daya manusia yang berkualitas sehingga menentukan keberhasilan dunia pendidikan di Indonesia (Hariyanti, 2019;Nurjanah, 2018). Di dalam dunia pendidikan, guru dituntut menjadi pendidik yang kreatif terutama dalam membuat media pembelajaran. Adanya jenjang pendidikan, membuat guru harus memikirkan media yang tepat bagi siswanya (Asmara, 2015; Nur Hidayah \& Nurhadija, 2018). Apalagi jika seorang guru harus mengajar siswa yang masih duduk di bangku Taman Kanak. Perubahan zaman, terutama pada teknologi mengharuskan guru untuk berinovasi dalam membuat media sehingga menjadi pendidik yang kreatif. Pemilihan media dan materi yang mudah dipahami merupakan hal yang harus dipikirkan oleh guru agar materi dapat tersampaikan kepada siswa itu sendiri. Menggunakan media pembelajaran merupakan salah satu sarana yang dapat memajukan pendidikan (Ratnasari, 2019; Hariyanti, 2019). Selain media, empati merupakan salah satu upaya dalam meningkatkan keberhasilan pendidikan di Indonesia. Nilai-nilai empati yang diajarkan dengan mencontoh perilaku guru atau orang tua dan menerapkan nilai nilai empati yang diajarkan (Nashukah, 2013;Syafitri, 2020). Empati adalah kemampuan yang dimiliki seseorang untuk bisa memahami, merasakan dan menempatkan dirinya dalam kondisi, sudut pandang dan perasaan orang lain yang kemudian mengekspresikan dengan situasi dari orang tersebut dengan sikap yang tepat (Hutasuhut \& Yaswinda, 2020; Mashar, 2015; Rahmawati, 2015).

Namun kenyataan yang terjadi bahwa kegagalan bagi pembentukan sikap dan keterampilan sosial terjadi beberapa waktu ini di berbagai kota di Indonesia yang menunjukkan hampir setiap hari sering muncul di media pemberitaan televisi bahwa berbagai bentuk krisis sosial khususya sudah cukup memprihatinkan seperti kurang disiplin, kurang empati terhadap masalah sosial, kurang efektif dalam berkomunikasi, bentuk perilaku kekerasan, pemaksaan kehendak, konflik antar kelompok dan tawuran (Pertiwi, 2020a; Setiantono, 2012). Berkurangnya rasa kepedulian terhadap sesama, rasa saling menghargai, hingga tidak adanya sikap toleransi menjadikan banyaknya kasus bentrok antar warga, hingga perang antar suku yang tidak jelas permasalahannya, sehingga nilai-nilai kearifan yang mulai luntur tergerus oleh perkembangan zaman menjadi salah satu bencana bagi kehidupan masyarakat (Hidayah, 2018; Sutanti, 2015). Tidak hanya itu saja, di dalam dunia pendidikan juga terdapat krisis sosial terutama bagi siswa. Mulai dari perkelahian antar teman, kurangnya sopan santun antara teman maupun guru yang mengajar di kelas. Rendahnya perilaku empati anak kelompok B yang ada di TK tersebut (Anggraini, 2020;Arofa, 2018). Hal tersebut terlihat dari anak kurang mampu mengenali perasaan temannya dan belum mampun merespon secara empatik (Juanda, 2019; Tarini, 2018). Berdasarkan hasil observasi dan wawancara yang dilakukan dengan guru Kelompok B didapatkan hasil bahwa media yang digunakan untuk dapat menstimulasi kemampuan empati anak Kelompok B masih belum banyak dan bervariasi, minat belajar anak masih kurang dalam pembelajaran, dan beberapa anak masih kurang dalam kemampuan empatinya. Hal ini juga didukung berdasarkan peneliti sebelumnya dalam penelitian tersebut dinyatakan bahwa buku cerita bergambar dinilai baik sebagai media penanaman karakter religius, toleransi, bersahabat, peduli sosial, disiplin, dan cinta damai serta baik digunakan sebagai media pengembang kreativitas anak usia dini khususnya anak usia 5-6 tahun (Miranda, 2018). Selain itu kemampuan empati anak kelompok B masih belum berkembang dengan baik. Perilaku ini ditunjukkan dari sikap anak yang tidak mau menjalin pertemanan dengan anak berkebutuhan khusus serta anak belum mampu berbagi dengan anak berkebutuhan khusus (Mardliyah, 2020; Pertiwi, 2020b; Rachmah, 2014).

Solusi yang dapat diberikan yaitu dengan memberikan cerita kepada anak. Cerita yang disampaikan kepada anak dapat menanamkan nilai-nilai empati dapat digunakan untuk mengasah perasaan, pemahaman, dan perilaku empati (Asiah, 2019; Mardliyah, 2020). Orang tua, guru, dan orang dewasa dapat membantu anak untuk mengembangkan empati dengan cara memberikan contoh, memberikan pemahaman serta mendorong anak untuk mencapai kemampuan empati sebagaimana yang seharusnya ditunjukkan oleh anak (Mawarani, 2019;Nurfazrina, 2020). Cerita yang disampaikan kepada anak cocok digunakan dalam mengembangkan sikap empati anak usia dini, karena dengan penyampaian cerita anak akan lebih mudah dalam mengadopsi pesan-pesan dan inti cerita (Asmara, 2015;Nurani, 2016). Mengembangkan empati pada anak dapat dilakukan dengan menyampaikan suatu cerita yang didalamnya mengandung nilai-nilai empati dalam kehidupan sehari-hari dan disampaikan dengan mengajak anak membaca dan mendengarkan sebuah buku cerita (Rosyadi, 2020;Tarigan, 2019). 
Temuan penelitian sebelumnya menyatakan buku cerita bergambar merupakan kombinasi dari gambar dan teks. Kombinasi gambar dan teks yang baik sangat diperlukan agar dapat menyampaikan pesan dalam buku tersebut (Handayani, 2020;N. Hidayah, 2021). Buku cerita yang diberikan kepada anak biasanya dilengkapi dengan gambar-gambar sehingga dapat menarik perhatian anak untuk melihat atau membaca buku tersebut (Y. A. S. Dewi, 2018; Halim, 2019). Buku cerita bergambar dapat menarik perhatian anak untuk belajar dan lebih cepat mengerti jika diberi visualisasi yang menarik dan memiliki banyak warna, karena anak-anak menyukai sesuatu yang kreatif (Wicaksono, 2019;Vindaswari, 2018). Kehadiran buku cerita bergambar menjadi sesuatu yang sangat disukai oleh anak-anak dan juga sebagai salah satu sumber pembelajaran (Kurniawati, 2020;Suryaningsih, 2017). Buku cerita bergambar mengandung cerita kehidupan sehari-hari, imajinatif, dan memiliki penanaman nilai kehidupan yang terkesan tidak memaksa (A. D. Putri, 2020;Rosvita, 2021). Temuan lain juga menyatakan buku cerita bergambar digital berbasis audio visual ini adalah sebuah bahan ajar yang dikemas untuk pembelajaran mandiri dan dapat menggantikan peran guru dalam memberikan pembelajaran kepada anak dalam membentuk dan menstimulasi kemampuan empati anak (Misnawan, 2020;Q. Putri, 2021). Pembelajaran atau bercerita guru akan menggunakan media ini dan diiringi oleh suara atau musik yang mendukung pesan-pesan atau informasi yang ingin disampaikan dalam pembelajaran (Astami, 2019; Fujiyanto, 2016).

Buku cerita bergambar digital berbasis audio visual ini dikembangkan menggunakan aplikasi Adobe Flash CS 6 sebagai program utama dengan berbantuan beberapa program seperti Microsoft Word 2013, Clip Studio Paint, Bandicam, Viva Video, dan Adobe Flash CS6. Pentingnya pengembangan buku cerita bergambar digital berbasis audio visual ini diharapkan anak dapat belajar mengenal lingkungan sekitarnya dengan membaca sebuah cerita di buku dalam bentuk digital. Kegiatan membaca yang dilakukan anak tidak lepas juga dengan bantuan audio cara membaca setiap teks yang terdapat di buku cerita sehingga anak akan mudah mengerti dan memahami isi atau makna yang terkandung dalam buku cerita. Pengembangan media ini untuk menstimulasi empati anak, sehingga ketika anak membaca buku cerita berbasis audio visual harapannya anak akan mengerti makna yang terkandung dalam buku. Kegiatan membaca buku cerita digital berbasis audio visual membuat anak dapat membaca di handphone tanpa membawa buku kemana-mana. Tujuan pada penelitian ini yaitu untuk menciptakan buku cerita bergambar digital berbasis audio visual dalam upaya untuk menstimulasi kemampuan empati anak kelompok B.

\section{METODE}

Jenis penelitian ini adalah penelitian pengembangan atau research and development (R\&D). Model pengembangan yang digunakan adalah model ADDIE (Analyze, Design, Development, Implementation, Evaluation) sebagai pedoman dalam menghasilkan produk dan menguji validitasnya. Adapun rancangan pelaksanaan model ADDIE dapat dilihat pada gambar 1

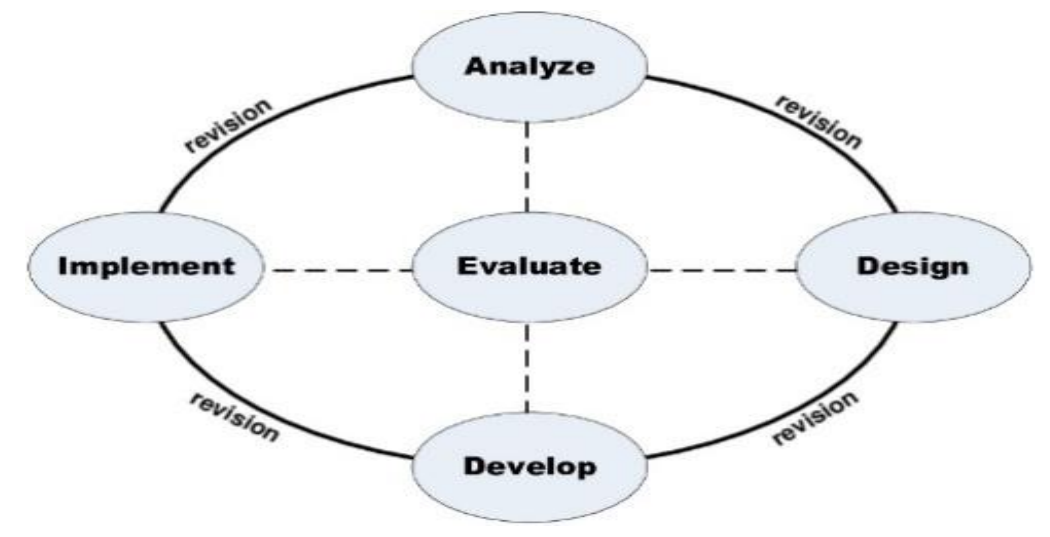

Gambar 1. Rancangan Model Desain ADDIE

ADDIE merupakan salah satu model desain pembelajaran yang sistematik yang dikembangkan secara terprogram dengan urutan tahapan yang sistematis dalam upaya mengembangkan suatu produk dalam upaya memecahkan suatu pemecahan masalah yang berhubungan dengan masalah belajar (Tegeh, 2014). Model pengembangan ADDIE memiliki 5 langkah tahapan yang terdiri atas Analysis, Design, Development, Implementation dan Evaluation yang dapat diterapkan pada saat mengembangkan suatu produk yang dapat digunakan dalam menunjang proses pembelajaran seperti buku ajar, modul pembelajaran, video pembelajaran, dan juga untuk media multimedia. Berdasarkan rancangan model 
penelitian yang dipilih, prosedur penelitian yang digunakan dalam penelitian dan pengembangan ini terdiri atas tahap analisis (analyse), perancangan (design), Pengembangan (development), Implementasi (implementation), dan evaluasi (evaluation). Tahap pertama adalah tahap analisis yang dilakukan untuk mengetahui kebutuhan dan masalah yang ada di TK Kumara Sari Denpasar. Tahap selanjutnya adalah perancangan yang dilakukan untuk memperjelas dan memudahkan pengembangan aplikasi buku cerita bergambar anak. Tahap pengembangan, dilakukan dengan mengembangkan aplikasi buku cerita bergambar anak serta melaksanakan uji coba produk yang terdiri atas uji ahli materi, uji ahli desain pembelajaran, uji ahli media pembelajaran, dan uji coba perorangan. Tahap implementasi dilakukan dengan menerapkan produk dalam proses pembelajaran. Namun, tahap uji coba kelompok kecil, dan uji coba lapangan tidak dilaksanakan karena keterbatasan yang diakibatkan oleh adanya pandemi Covid-19. Tahap evaluasi dilakukan untuk mengukur dan menilai aplikasi buku cerita bergambar digital berbasis audio visual yang telah diterapkan pada setiap tahapan untuk penyempurnaan atau memperbaiki hasil produk yang dikembangkan. Subjek uji coba yang terlibat pada penelitian ini terdiri atas ahli materi, ahli desain pembelajaran, ahli media pembelajaran, dan tiga orang anak kelompok B. Metode pengumpulan data yang digunakan yaitu metode non tes yang meliputi observasi, wawancara, dan angket. Instrumen yang digunakan untuk mengumpulkan data adalah angket dapat dilihat pada tabel 1, 2, 3 dan 4 .

Tabel 1. Kisi-Kisi Instrumen Ahli Materi

\begin{tabular}{llcc}
\hline No & \multicolumn{1}{c}{ Komponen } & Nomor Butir & Jumlah Butir \\
\hline \multirow{2}{*}{1} & 1) Kesesuaian materi dengan kompetensi dasar & 1 & 1 \\
1) Kesesuaian materi dengan indikator pembelajaran & 2 & 1 \\
& 2) Kesesuaian materi dengan tujuan pembelajaran & 3 & 1 \\
3) Ketepatan materi & 5 & 1 \\
1) Kemenarikan materi & 4,7 & 2 \\
1) Materi mudah dipahami & 9 & 1 \\
2) Materi bermanfaat bagi anak dalam kehidupan nyata & 6 & 1 \\
3) Penggunaan bahasa yang tepat dan konsisten & 8 & 1 \\
4) Kesesuaian evaluasi dengan materi & 15 & 1 \\
5) Memberikan umpan balik hasil evaluasi materi & 10,12 & 2 \\
7) Membantu mengingat kemampuan dan pengetahuan & 14 & 1 \\
sebelumnya & 11 & 1 \\
1) Diberikan petunjuk penggunaan & 13 & 1 \\
\hline & Jumlah & & $\mathbf{1 5}$ \\
\hline
\end{tabular}

Tabel 2. Kisi-Kisi Instrumen Ahli Desain Pembelajaran

\begin{tabular}{|c|c|c|c|c|c|}
\hline No & Aspek & & Komponen & Nomor Butir & Jumlah Butir \\
\hline & & 1) & Kejelasan tujuan umum pembelajaran & $1,2,3,4$ & 4 \\
\hline \multirow[t]{3}{*}{1} & Tujuan & 2) & Kesesuaian indikator pembelajaran & & \\
\hline & & 3) & Kejelasan tujuan pembelajaran & & \\
\hline & & 1) & $\begin{array}{l}\text { Penyampaian materi memberikan langkah- } \\
\text { langkah yang logis dan alur navigasi yang } \\
\text { bebas }\end{array}$ & 5 & 1 \\
\hline \multirow[t]{3}{*}{2} & Strategi & 2) & $\begin{array}{l}\text { Membantu mengingat kemampuan dan } \\
\text { pengetahuan sebelumnya }\end{array}$ & 8 & 1 \\
\hline & & 3) & $\begin{array}{l}\text { Memberikan contoh-contoh dalam } \\
\text { penyajiannya }\end{array}$ & 9 & 1 \\
\hline & & 4) & Penyampaian materi yang menarik & 6,7 & 2 \\
\hline \multirow[t]{2}{*}{3} & Evaluasi & 1) & $\begin{array}{l}\text { Diberikan evaluasi untuk mengukur } \\
\text { kemampuan anak }\end{array}$ & 10 & 1 \\
\hline & & & Jumlah & & 10 \\
\hline
\end{tabular}

Tabel 3. Kisi-Kisi Instrumen Review Ahli Media Pembelajaran

\begin{tabular}{ccrlcc}
\hline No & Aspek & & Komponen & Nomor Butir & Jumlah Butir \\
\hline \multirow{2}{*}{1} & \multirow{2}{*}{ Tampilan } & 1) & Kemudahan penggunaan & 1 & 1 \\
& & 2) & Kualitas tampilan & 6 & 1 \\
& & 3) & Konsistensi tombol & 3 & 1
\end{tabular}




\begin{tabular}{ccclcc}
\hline No & Aspek & \multicolumn{1}{c}{ Komponen } & Nomor Butir & Jumlah Butir \\
\hline 2 & Teks & 1) & Keterbacaan & $2,7,10$ & 3 \\
3 & Gambar & 1) & Kesesuaian gambar & 8 & 1 \\
4 & Warna & 2) & $\begin{array}{l}\text { Komposisi dan kombinasi warna yang tepat } \\
\text { dan serasi }\end{array}$ & 4 & 1 \\
5 & Suara & 1) & Penggunaan musik yang sesuai & 5,9 & 2 \\
\hline & $\quad$ Jumlah & & $\mathbf{1 0}$ \\
\hline
\end{tabular}

Tabel 4. Kisi-Kisi Instrumen Uji Coba Perorangan

\begin{tabular}{cccccc}
\hline No & Aspek & & \multicolumn{1}{c}{ Komponen } & Nomor Butir & Jumlah Butir \\
\hline \multirow{2}{*}{1} & & 1) & Kemenarikan media pembelajaran & 1 & 1 \\
& & 2) & Kemudahan penggunaan media & 3 & 1 \\
2 & 1) & Keterbacaan teks & 4 & 1 \\
& & 2) & Penggunaan jenis huruf yang sesuai & 2 & 1 \\
3 & 3) & Penggunaan ukuran huruf yang sesuai & 5 & 1 \\
4 & Gambar & 1) & Penggunaan gambar yang sesuai dengan & 6 & 1 \\
5 & Motivasi & 1) & Media dapat membangkitkan motivasi anak & 7 & 2 \\
& 1) & Kemenarikan materi yang disampaikan & & \\
6 & Materi & 2) & Materi yang mudah dipahami & 9,11 & 2 \\
\hline
\end{tabular}

(Suartama, 2016)

Data yang diperoleh berupa data kuantitatif dan data kualitatif sehingga teknik analisis data yang digunakan yaitu teknik analisis deksriptif kuantitatif dan teknik analisis deskriptif kualitatif. Metode analisis deskriptif kuantitatif merupakan cara mengolah atau menganalisis data dengan menyusun secara sistematis dalam bentuk angka-angka dan atau persentase, mengenai suatu objek yang diteliti, sehingga diperoleh kesimpulan umum (Agung, 2014). Data skor yang diperoleh dari para ahli dalam penelitian ini dianalisis menggunakan skala likert yang terdiri dari 4 yang disajikan pada tabel 5 dan 6 .

Tabel 5. Kategori Penilaian Skala Likert Dengan Skala 4

\begin{tabular}{ccc}
\hline No & Skor & Keterangan \\
\hline 1 & Skor 4 & Sangat Setuju/SS \\
2 & Skor 3 & Setuju/S \\
3 & Skor 2 & Tidak Setuju/TS \\
4 & Skor 1 & Sangat Tidak Setuju/STS \\
\hline
\end{tabular}

(Sugiyono, 2019)

Tabel 6. Konversi Tingkat Pencapaian dengan Skala 5

\begin{tabular}{ccc}
\hline Tingkat Pencapaian (\%) & Kualifikasi & Keterangan \\
\hline $90-100 \%$ & Sangat Baik & Tidak perlu direvisi \\
$75-89 \%$ & Baik & Sedikit direvisi \\
$65-74 \%$ & Cukup & Direvisi secukupnya \\
$55-64 \%$ & Kurang & Banyak hal yang direvisi \\
$0-54 \%$ & Sangat Kurang & Diulangi membuat produk \\
\hline
\end{tabular}

(Tegeh, 2014)

Penelitian pengembangan ini menggunakan teknik analisis deskriptif kualitatif dan analisis statistik deskriptif kuantitatif. Teknik analisis data deskriptif kualitatif, dilakukan dengan mengelompokkan hasil dari angket yang berupa masukan, tanggapan, kritik dan saran perbaikan dari para pakar ahli. Hasil analisis dari data yang didapat ini kemudian digunakan untuk merevisi produk yang dikembangkan. Analisis data deskriptif kuantitatif dilakukan dengan cara menganalisis data dari angket yang sebelumnya telah diberikan kepada responden yang terdiri atas ahli materi, ahli media dan ahli desain pembelajaran, dari hasil uji coba perorangan anak Kelompok B di TK Kumara Sari Denpasar Tahun Ajaran 2020/2021. Data yang didapat dari angket berupa pernyataan mengenai tingkat kelayakan dari 
masing-masing aspek kemudian dianalisis. Selanjutnya skor berupa angka dari hasil jawaban responden pada angket, yang disusun berdasarkan skala linkert dengan skala 4 yang dianalisis untuk mengetahui persentase kelayakgunaan media pembelajaran yang dikembangkan. Hasil analisis data kuantitatif berupa persentase kelayakan produk dan respon dari subyek penelitian, kemudian dianalisis menggunakan kriteria kelayakan media buku cerita bergambar digital berbasis audio visual, sehingga dapat diambil suatu keputusan mengenai layak atau tidaknya media aplikasi ini yang dikembangkan. Berikut dipaparkan mengenai analisis yang dilakukan terhadap angket dari responden penelitian. Analisis kelayakan media dari ahli materi, ahli media pembelajaran dan ahli desain pembelajaran dan uji coba perorangan. Jawaban yang terkumpul dari angket ahli media pembelajaran, ahli materi, ahli desain pembelajaran dan uji coba perorangan dianalisis menggunakan skala Likert yang telah dimodifikasi peneliti menjadi skala empat dan disajikan pada tabel 7 dan 8 .

Tabel 7. Kategori Penilaian Skala Likert dengan Skala 4

\begin{tabular}{ccc}
\hline No & Skor & Keterangan \\
\hline 1 & Skor 4 & Sangat Setuju/SS \\
2 & Skor 3 & Setuju/S \\
3 & Skor 2 & Tidak Setuju/TS \\
4 & Skor 1 & Sangat Tidak Setuju/STS \\
\hline
\end{tabular}

(Sugiyono, 2016)

Tabel 8.Konversi Tingkat Pencapaian dengan Skala 5

\begin{tabular}{ccc}
\hline Tingkat Pencapaian (\%) & Kualifikasi & Keterangan \\
\hline $90-100 \%$ & Sangat Baik & Tidak perlu direvisi \\
$75-89 \%$ & Baik & Sedikit direvisi \\
$65-74 \%$ & Cukup & Direvisi secukupnya \\
$55-64 \%$ & Kurang & Banyak hal yang direvisi \\
$0-54 \%$ & Sangat Kurang & Diulangi membuat produk \\
\hline
\end{tabular}

(Tegeh, 2014)

\section{HASIL DAN PEMBAHASAN}

Hasil

Rancang bangun pengembangan media pembelajaran buku cerita bergambar anak ini mengikuti model pengembangan ADDIE yang terdiri dari tahap analisis, tahap desain, tahap pengembangan, tahap implementasi, dan tahap evaluasi. Adapun hasil pada tiap tahapan yang telah dilaksanakan yaitu pada analisis kondisi awal terhadap keadaanya yang terjadi di lapangan. Hasil analisis terhadap jalannya pembelajaran, diketahui bahwa dalam proses pembelajaran yang telah berlangsung secara daring sangat kurang adanya interaksi secara langsung antara guru dengan anak. Pembelajaran menggunakan sarana Whatssapp Group WAG kelas dan masih minim dengan penggunaan media pembelajaran yang interaktif dan bervariasi. Proses pembelajaran guru masih menggunakan media berupa video pembelajaran yang diunduh dari internet seperti youtube yang kemudian dikirimkan ke WAG. Guru dalam pembelajaran hanya menggunakan WAG dan jarang menggunakan sarana pembelajaran lainya seperti video converence seperti Zoom, dikarenakan adanya keluhan orang tua terhadap penggunaan sarana belajar yang menggunakan kuota internet yang besar. Sehingga dalam pembelajaran guru hanya menggunakan sarana WAG. Pembelajaran daring yang dilakukan hanya di rumah bersama dengan orang tua mengakibatkan guru hanya mengawasi anak melalui foto, video dan tugas yang dikumpulkan orang tua. Guru menstimulasi kemampuan empati anak hanya mengandalkan buku majalah dan belum memiliki media yang dapat digunakan agar pembelajaran lebih menyenangkan. Keterbatasan interaksi dengan anak mengakitbatkan guru tidak dapat terlalu banyak mengetahui bagaimana perkembangan kemampuan empati anak yang sebenarnya di rumah. Berdasarkan permasalahan tersebut diketahui bahwa dalam proses pembelajaran sangat diperlukan suatu media pembelajaran yang bersifat interaktif yang dapat digunakan sebagai sarana penunjang pembelajaran bagi anak. Pada analisis kompetensi dasar dan indikator kemampuan empati anak peneliti melakukan analisis terhadap KD dan merumuskan indikator pembelajaran yang dilaksanakan dengan cara melakukan wawancara bersama guru kelas untuk mengetahui muatan materi yang dirasa memerlukan adanya media pembelajaran yang inovatif. Gu kelas, diketahui bahwa materi yang biasanya dapat digunakan untuk menstimulasi kemampuan empati pada anak adalah memberikan contoh nyata kepada anak. 
Kedua, tahap perancangan/ design. Pada tahap ini terdiri atas 3 proses, yang meliputi tahap pengumpulan data, penyusunan flowchart dan penyusunan storyboard aplikasi buku cerita bergambar anak. Pada tahap pengumpulan data ini dilaksanakan pengumpulan data berupa materi mengenai empati pada anak usia dini, cerita-cerita yang dapat menstimulasi kemampuan empati anak, gambar, musik/audio, tampilan aplikasi, ikon tombol, yang semuanya diperlukan dalam proses pembuatan aplikasi buku cerita. Materi yang dicantumkan dalam aplikasi nantinya disesuaikan dengan rencana pelaksaan pembelajaran harian tema lingkungan dan sub tema teman bermain, yang selanjutnya materi tersebut digunakan sebagai materi pada aplikasi yang dikembangkan. Tahap pembuatan flowchart dilaksanakan dengan membuat dan menyusun bagan alur yang digunakan pada aplikasi buku cerita bergambar digital berbasis audio visual. Flowchart adalah suatu bagan alur yang terdiri dari simbol-simbol yang menunjukkan bagaimana langkah kerja atau alur pada program. Pembuatan flowchart bertujuan untuk memudahkan bagaimana materi yang dikumpulkan sebelumnya dapat ditampilkan pada aplikasi. adapun flowchart aplikasi buku cerita bergambar anak yaitu sebagai berikut: Tahap pembuatan storyboard dilaksanakan dengan membuat sketsa berupa gambar tampilan aplikasi buku cerita yang dikembangkan. Storyboard adalah sketsa gambar yang disusun secara sistematis yang memuat gambaran tampilan produk yang dikembangkan. Storyboard digunakan untuk mempermudah dalam penyampaian ide cerita dan sketsa rancangan tampilan aplikasi yang dikembangkan.

Ketiga, pada tahap Pengembangan (development) ini, buku cerita bergambar anak mulai dikembangkan dengan berpedoman pada storyboard yang telah dibuat. Proses pengembangan buku cerita diawali dengan pengumpulan bahan-bahan berupa pengumpulan atau pembuatan cerita, gambar, suara, background dan yang nantinya disatukan dalam proses penyuntingan. Produksi buku cerita bergambar anak dibuat dengan menggunakan aplikasi microsoft word, clip studio paint, bandicam, viva video, dan adobe flash cs6. Setelah bahan-bahan dibuat selanjutnya disatukan pada aplikasi. Hasil analisis data tahap pengembangan buku cerita bergambar digital ini memaparkan hasil evaluasi produk yaitu analisis hasil uji validitas pengembangan buku cerita bergambar digital. Adapun rincian hasil analisis data tersebut yaitu hasil analisis validitas Uji Ahli dan Uji Coba Produk. Hasil analisis validitas memaparkan empat pembahasan yaitu uji ahli materi, uji ahli desain pembelajaran, uji ahli media pembelajaran dan uji coba perorangan. Adapun hasil validitas pengembangan buku cerita bergambar digital dari ahli materi, ahli desain pembelajaran, ahli media pembelajaran, dan uji coba perorangan.

Berdasarkan persentase hasil validitas pengembangan buku cerita bergambar anak dapat diketahui bahwa persentase hasil validitas pengembangan buku cerita bergambar digital berbasis audio visual menurut subjek uji coba dari uji ahli materi memperoleh persentase hasil validasi sebanyak $85 \%$ dengan kualifikasi persentase baik. Selanjutnya dari uji ahli desain pembelajaran dengan persentase hasil validasi sebanyak 85\% dengan kualifikasi persentase baik. Uji Ahli media pembelajaran dengan persentase hasil validasi sebanyak $85 \%$ dengan kualifikasi persentase baik. Terakhir, dari uji coba perorangan dengan persentase hasil validasi $97 \%$ dan kualifikasi persentase sangat baik. Adapun pemaparan hasil validitas pengembangan buku cerita bergambar digital berbasis audio visual secara lebih rinci. Hasil skor yang diperoleh dari ahli materi selanjutnya dikonversikan dengan tabel konversi tingkat pencapaian skala 5. Berdasarkan perhitungan, persentase tingkat pencapaian perolehan dari ahli materi adalah $85 \%$ berada pada kualifikasi baik, sehingga buku cerita bergambar digital layak digunakan dengan revisi. Hasil skor yang diperoleh dari ahli desain pembelajaran selanjutnya dikonversikan dengan tabel konversi tingkat pencapaian skala 5. Berdasarkan perhitungan, persentase tingkat pencapaian perolehan dari ahli desain pembelajaran adalah $85 \%$ berada pada kualifikasi baik, sehingga buku cerita bergambar digital layak digunakan dengan revisi. Hasil skor yang diperoleh dari ahli media pembelajaran selanjutnya dikonversikan dengan tabel konversi tingkat pencapaian skala 5. Berdasarkan perhitungan, persentase tingkat pencapaian perolehan dari ahli media pembelajaran adalah $85 \%$ berada pada kualifikasi baik, sehingga buku cerita bergambar digital layak digunakan dengan revisi. Hasil skor yang diperoleh dari uji coba perorangan selanjutnya dikonversikan dengan tabel konversi tingkat pencapaian skala 5 . Berdasarkan perhitungan, persentase tingkat pencapaian perolehan dari uji coba perorangan adalah $97 \%$ berada pada kualifikasi sangat baik, sehingga buku cerita bergambar digital tidak perlu direvisi. Berdasarkan perolehan uji validitas tersebut, dapat disimpulkan bahwa buku cerita bergambar digital berbasis audio visual untuk menstimulasi kemampuan empati anak valid sehingga layak untuk digunakan dalam proses pembelajaran.

Tahap implementasi produk yang dikembangkan pada pembelajaran tidak dapat dilaksanakan dikarenakan penelitian ini dilakukan pada situasi pandemi covid-19 yang menyebabkan kegiatan pembelajaran tidak dapat dilaksanakan secara konvensional di Taman Kanak-kanak dan adanya himbauan dari dinas pendidikan Kota Denpasar yang masih melarang diadakannya kegiatan yang menimbulkan keramaian di lingkungan sekolah dan harus melaksanakan kegiatan pembelajaran dengan sistem daring. Tahap evalusi adalah tahapan yang dilakukan untuk mengevaluasi produk yang 
dikembangkan. Evaluasi terhadap produk dilaksanakan berdasarkan data-data yang telah dikumpulkan pada tahap sebelumnya yang dijadikan acuan pengembangan produk agar memiliki kualitas yang baik. Jenis evaluasi yang dilaksanakan adalah terbatas pada evaluasi formatif yaitu evaluasi yang dilakukan untuk mengetahui hasil penilaian produk yang dikembangkan, apakah buku cerita bergambar digital berbasis audio visual sudah baik dan layak diterapkan dalam pembelajaran atau tidak.

Penelitian ini menggunakan model pengembangan ADDIE yang memiliki 5 langkah tahapan yaitu Analysis, Design, Development, Implementation dan Evaluation yang dapat diterapkan pada saat mengembangkan suatu produk yang dapat digunakan dalam menunjang proses pembelajaran seperti buku ajar, modul pembelajaran, video pembelajaran, dan juga untuk media multimedia. Namun pada tahap ke empat yaitu tahap implementasi yang dilakukan dengan menerapkan produk dalam proses pembelajaran yang meliputi tahap uji coba kelompok kecil, dan uji coba lapangan tidak dilaksanakan karena keterbatasan. Dalam penelitian ini uji coba produk yang dilaksanakan sebatas hanya pada uji coba perorangan. Hal ini dakarenakan situasi pandemi covid-19 yang menyebabkan kegiatan pembelajaran tidak dapat dilaksanakan secara tatap muka dan harus menggunakan sistem daring dan arahan dinas pendidikan yang melarang kegiatan pembelajaran yang menimbulkan keramaian di sekolah guna mengurai penyebaran covid-19.

Berdasarkan penilaian dari pakar ahli, diketahui bahwa buku cerita bergambar digital berbasis audio visual yang telah dikembangkan, sudah sesuai dan layak untuk digunakan dalam kegiatan pembelajaran khususnya pada untuk menstimulasi kemampuan empati anak. Hal initersebut dilihat dari beberapa aspek. Pertama, dari aspek materi bahwa buku cerita bergambar digital berbasis audio visual berada pada kategori baik dengan sedikit revisi, yang ditinjau dari isi dan naskah materi, kesesuaian materi yang ditampilkan dengan kompetensi dasar, indikator dan tujuan pembelajaran, kebenaran konsep dan teori serta penggunaan tata bahasa yang sesuai. Penyajian materi pada media buku cerita yang dikembangkan, disusun sesuai dengan kompetensi dasar dan indikator yang sesuai dengan tujuan pembelajaran yang hendak dicapai. Berdasarkan validasi dari ahli materi maka dapat diketahui bahwa buku cerita bergambar digital berbasis audio visual yang telah dikembangkan sudah layak sehingga dapat dipergunakan dalam kegiatan pembelajaran anak. Media pembelajaran merupakan alat yang dapat memperjelas penyajian pesan dan informasi sehingga dapat memperlancar dan meningkatkan proses dan hasil belajar (Surachman, 2020; Puspitasari, 2017).

Kedua, aspek media pembelajaran bahwa buku cerita bergambar digital berbasis audio visual berada pada kategori baik, ditinjau dari sisi desain media yang dikembangkan dan kesesuaian materi dengan media yang dikembangkan yang didalamnya terdapat gambar, audio yang dirancang menarik dan sesuai dengan perkembangan anak, sehingga diharapkan mampu menjadikan anak semangat belajar. Berdasarkan penilaian dari pakar ahli media, diketahi bahwa buku cerita bergambar digital berbasis audio visual yang telah dikembangkan, ditinjau dari segi media pembelajaran sudah sesuai dan layak untuk digunakan dalam kegiatan pembelajaran khususnya pada untuk menstimulasi kemampuan empati anak.

Buku cerita bergambar digital berbasis audio visual merupakan salah satu media pembelajaran yang dapat digunakan guru pada saat proses pelaksanaan pembelajaran. Buku cerita bergambar digital berbasis audio visual ini mampu memberikan anak kegiatan membaca dalam mengembangkan potensi setiap aspek perkembangan anak. Potensi tersebut seperti menambah perbendaharaan bahasa pada anak dan pesan moral yang terkandung pada cerita, dapat menstimulasi kemampuan sosial emosional anak terutama pada kemampuan empati anak terhadap orang lain. Selain itu buku cerita bergambar adalah buku yang didalamnya terdapat cerita dan dilengkapi dengan ilustrasi gambar, teks atau percakapan yang disampaikan dengan bahasa yang ringan sehingga mudah dipahami serta mengandung pesan moral yang dapat diterapkan dalam kehidupan sehari-hari (Nugraheni, 2019;Pratiwi, 2017).

Temuan ini diperkuat dengan penelitian sebelumnya menyatakan metode bercerita berbasis kearifan lokal berpengaruh terhadap kemampuan empati anak (N. P. D. S. Dewi, 2019). Temuan lain menyatakan media bigbook berbasis cerita rakyat efektif digunakan untuk meningkatkan empati dan kemampuan bercerita anak usia 5-6 tahun (Dheasari, 2020; Rahmadianti, 2020). Dari pembahasan diatas media buku cerita dapat mempengaruhi kemampuan empati pada anak. Hal ini dilihat dari validitas buku cerita bergambar yang berbasis media audio visual. Karena perkembangan teknologi yang semakin maju maka perlunya pengembangan media pembelajaran yang tentunya dapat bermanfaat bagi siswa maupun guru dalam proses pelaksanaan pembelajaran, terutama sikap sosial pada anak. Media ini tidak hanya berisikan cerita saja akan tetapi juga gambar yang dapat menarik perhatian anak, apalagi media ini deperuntukan bagi anak yang masih di tingkatan TK agar pada saat anak menonton cerita bergambar tersebut anak tidak akan bosan. Media ini berisi cerita yang menarik dengan tujuan untuk menstimulasi rasa empati pada anak, ditambah dengan gambar dan visual yang sangat jarang di temukan pada media lainnya. Selain itu ditambah dengan kegagalan pembentukan sikap sosial pada anak maka media ini dianggap cocok untuk menstimulasi kemampuan empati pada anak. Implikasi dari penelitian ini yaitu 
media pembelajaran buku cerita bergambar anak mampu untuk menarik minat belajar anak sehingga penyampaian materi menjadi lebih menarik dan bervariasi. Untuk pengembangan ilmu pengetahuan, media pembelajaran buku cerita bergambar anak dapat dijadikan sebagai inovasi yang memadukan teknologi sebagai media pembelajaran untuk menstimulasi kemampuan empati anak.

\section{SIMPULAN}

Media buku cerita bergambar digital berbasis audio visual terhadap stimulasi kemampuan empati anak usia dini, maka dapat disimpulkan bahwa pemanfaatan buku cerita bergambar digital berbasis audio visual dapat menstimulasi kemampuan anak usia dini. Hal ini terbukti berdasarkan hasil validitas pengembangan buku cerita bergambar anak telah dinyatakan valid oleh subjek penelitian. Guru dapat menerapkan pembelajaran aplikasi buku cerita bergambar anak untuk menstimulasi kemampuan empati anak. Guru dalam pembelajaran disarankan untuk dapat mengembangkan media pembelajaran yang sejenis secara mandiri yang dirasa perlu media penunjang yang inovatif dan sesuai.

\section{DAFTAR RUJUKAN}

Agung, A. A. G. (2014). Metodologi Penelitian Pendidikan. Aditya Media Publishing.

Anggraini, W. (2020). Penerapan Metode Bermain Peran (Role Playing) Dalam Mengembangkan Empati Pada Anak Usia 5-6 Tahun. Didaxei: Jurnal Pendidikan, 1(1), 41-52. https://doi.org/10.15642/jeced.v1i2.466.

Arofa, I. Z. (2018). Pengaruh Perilaku Bullying Terhadap Empati Ditinjau dari Tipe Sekolah. Jurnal Ilmiah Psikologi Terapan, 3(61), 89-100. https://doi.org/10.22219/jipt.v6i1.5435.

Asiah, A. (2019). Implementasi Sistem Full Day School dalam Mengembangkan Empati Anak Usia Dini. Golden Age: Jurnal Ilmiah Tumbuh Kembang Anak Usia Dini, 3(4), 247-258. https://doi.org/10.14421/jga.2018.34-03

Asmara, A. P. (2015). Pengembangan Media Pembelajaran Berbasis Audio Visual Tentang Pembuatan Koloid. Jurnal Ilmiah Didaktika, 15(2), 156. https://doi.org/10.22373/jid.v15i2.578.

Astami, N. W. R. (2019). Pengaruh Penggunaan Media Pembelajaran Audio Visual Terhadap Kemampuan Menyimak Kelompok B TK Gugus II Buleleng. Jurnal Pendidikan Anak Usia Dini Undiksha, 7(2), 206. https://doi.org/10.23887/paud.v7i2.18996.

Dewi, N. P. D. S. (2019). Pengaruh Metode Bercerita Berbasis Kearifan Lokal Terhadap Kemampuan Empati Anak Kelompok B1 TK Tunas Daud Kecamatan Denpasar Barat Tahun Ajaran 2018/2019. Jurnal Pendidikan Anak Usia Dini Undiksha, 7(1), 78-87. https://doi.org/10.23887/paud.v7i1.18761.

Dewi, Y. A. S. (2018). Penggunaan Media Buku Cerita Bergambar untuk Meningkatkan Kemampuan Bahasa Anak Kelompok B RA Riyadlul Jannah Wrati Kejayan Pasuruan. PROCEEDING: The 3rd Annual International on Islamic International Education, 3. https://doi.org/10.31219/osf.io/equkr.

Dheasari, A. E. (2020). Pengembangan Media Bigbook Cerita Rakyat Untuk Meningkatkan Empati dan Kemampuan Bercerita Anak Usia Dini. Edukasi: Jurnal Penelitian Dan Artikel Pendidikan, 12(1), 41-54. https://doi.org/10.31603/edukasi.v12i1.3705.

Fujiyanto, A. (2016). Penggunaan Media Audio Visual Untuk Meningkatkan Hasil Belajar Siswa Pada Materi Hubungan Antarmakhluk Hidup. Jurnal Pena Ilmiah, 1(1), 841-850. https://doi.org/10.23819/pi.v1i1.3576.

Halim, D. (2019). Dampak Pengembangan Buku Cerita Bergambar Untuk Anak Usia Dini. Jurnal Pendidikan Dan Kebudayaan, 9(3), 203-216. https://doi.org/10.24246/j.js.2019.v9.i3.p203-216.

Handayani, L. (2020). Pengembangan Buku Cerita Berbasis Pendidikan Karakter pada Ranah Sekolah bagi Siswa SMP Kelas VII di Kabupaten Kendal. Piwulang : Jurnal Pendidikan Bahasa Jawa, 8(2), $107-$ 115. https://doi.org/10.15294/piwulang.v8i2.33494.

Hariyanti. (2019). Meningkatkan Kemampuan Bahasa Ekspresif Anak Melalui Metode Bercerita Menggunakan Media Boneka Jari. Jurnal Penelitian PAUD, 3(2), 106-120. https://doi.org/10.33222/pelitapaud.v3i2.520.

Hidayah, N., \& Rohmatillah, R. (2021). Pengembangan Buku Cerita Bergambar Islami Berbasis Pendidikan Lingkungan Hidup untuk Pembelajaran Membaca di SD/MI. AR-RIAYAH : Jurnal Pendidikan Dasar, 5(1), 27. https://doi.org/10.29240/jpd.v5i1.2668.

Hutasuhut, A. R. S., \& Yaswinda, Y. (2020). Analisis Pengaruh Film Nussa dan Rara terhadap Empati Anak Usia Dini di Kota Padang. Jurnal Pendidikan Tambusai, 4(2), 1237-1246. https://doi.org/10.31004/jptam.v4i2.590.

Juanda, J. (2019). Pendidikan Karakter Anak Usia Dini melalui Sastra Klasik Fabel Versi Daring. Jurnal 
Obsesi : Jurnal Pendidikan Anak Usia Dini, 3(1), 39. https://doi.org/10.31004/obsesi.v3i1.126.

Kharisma, G. I., \& Arvianto, F. (2019). Pengembangan aplikasi android berbentuk education games berbasis budaya lokal untuk keterampilan membaca permulaan bagi siswa kelas 1 SD/MI. Premiere Educandum: Jurnal Pendidikan Dasar Dan Pembelajaran, 9(2), 203. https: //doi.org/10.25273/pe.v9i2.5234.

Kumalasani, M. P. (2018). Kepraktisan Penggunaan Multimedia Interaktif Pada Pembelajaran Tematik Kelas IV SD. Jurnal Bidang Pendidikan Dasar, 2(1A), 1-11. https: //doi.org/10.21067/jbpd.v2i1a.2345.

Kurniawati, R. T. (2020). Pengembangan Media Buku Cerita Bergambar Untuk Meningkatkan Kemampuan Membaca Siswa Kelas 1 Sekolah Dasar. Jurnal Pendidikan Guru Sekolah Dasar, 7(1), 29. https://doi.org/10.30997/dt.v7i1.2634.

Mardliyah, S. (2020). Sekolah Keluarga: Menciptakan Lingkungan Sosial untuk Membangun Empati dan Kreativitas Anak Usia Dini. Jurnal Obsesi : Jurnal Pendidikan Anak Usia Dini, 5(1), 576. https://doi.org/10.31004/obsesi.v5i1.665.

Mashar, R. (2015). Empati Sebagai Dasar Pembentukan KarakterAnak Usia Dini. In Jurnal Pendidikan Anak (Vol. 2, Issue 2). https://doi.org/10.21831/jpa.v2i2.3040.

Mawarani, G. (2019). Hubungan Antara Kecenderungan Internet Addiction Dengan Empati Pada Anak Sekolah Dasar. Cognicia, 7(1), 1-15. https://doi.org/10.22219/COGNICIA.Vol7.No1.\%25p.

Miranda, D. (2018). Pengembangan Buku Cerita Berbasis Pendidikan Karakter Untuk Meningkatkan Kreativitas PAUD. Jurnal Visi Ilmu Pendidikan, 10(1), 18-30. https://doi.org/10.26418/jvip.v10i1.25975.

Misnawan, I. W. (2020). Model Pembelajaran SQ3R Berbantuan Buku Cerita Meningkatkan Keterampilan Membaca Siswa. Jurnal Ilmiah Pendidikan Profesi Guru, 3(2), 282. https://doi.org/10.23887/jippg.v3i2.28266.

Nashukah, F. (2013). Perbedaan Kematangan Emosi Remaja Ditinjau Dari Struktur Keluarga. Jurnal Psikologi Teori Dan Terapan, 3(2), 93. https://doi.org/10.26740/jptt.v3n2.p93-102.

Nugraheni, I. (2019). Media Buku Cerita untuk Meningkatkan Kemampuan Membaca dan Menulis Siswa Kelas IV Sekolah Dasar. Journal of Education, 4(3), 322-329. https://doi.org/10.17977/jptpp.v4i3.12085.

Nur Hidayah, A., \& Nurhadija, N. (2018). Aktivitas Mendongeng Menggunakan Media Audio Visual Dalam Pembelajaran Moral. Jurnal Smart Paud, 1(1), 73. https://doi.org/10.36709/jspaud.v1i1.3523.

Nurani, I. (2016). Analisis Kebutuhan Pengembangan Media Audio Visual Pokok Bahasan Sintesis Protein Untuk SMA. Jurnal VARIDIKA, 28(1), 90-95. https://doi.org/10.23917/varidika.v28i1.1961.

Nurfazrina, S. A. (2020). Analisis Kemampuan Empati Anak Usia 5-6 Tahun (Literature Review). Jurnal PAUD Agapedia, 4(2), 285-299. https://doi.org/10.17509/jpa.v4i2.30447.

Nurjanah, E. (2018). Pengembangan Bahan Ajar Materi Mencerna (Menyimak Cerita Anak) Berbasis Cerita Anak Majalah Bobo. Jurnal Bidang Pendidikan Dasar (JBPD), 2(1), 69-83. https://doi.org/10.21067/jbpd.v2i1.2201.

Pertiwi, K. S. (2020a). Hasil Kemampuan Empati Anak Usia Dini Melalui Metode Bercerita Menggunakan Media E-Bigbook. Jurnal Edutech Undiksha, 8(1), 156-166. https://doi.org/10.23887/jeu.v8i1.27335.

Pertiwi, K. S. (2020b). Hasil Kemampuan Empati Anak Usia Dini Melalui Metode Bercerita Menggunakan Media E-Bigbook. Jurnal Edutech Undiksha, 8(1), 156-166. https://doi.org/10.23887/jeu.v8i1.27335.

Pratiwi, N. L. M. T. (2017). Pengembangan Buku Cerita Anak Dengan Menginsersi Budaya Lokal dalam Tema Kegemaranku Untuk Kelas I Sekolah Dasar. Jurnal Ilmiah Pendidikan Dan Pembelajaran, 1(1), 38-47. https://doi.org/10.23887/jipp.v1i3.11984.

Puspitasari, F. D. A. (2017). Pengembangan Buku Cerita Bergambar Berbasis Serat Wulangreh Pupuh Pangkur Untuk Pembelajaran Bahasa Jawa di SMP Kota Semarang. Journal of Javanese Learning and Teaching, 5(2), 17-25. https://doi.org/10.15294/piwulang.v7i2.29601.

Putri, A. D. (2020). Nilai Antikorupsi Dalam Buku Cerita Bergambar Peternakan Kakek Tulus dan Byur! KEMBARA:Journal of Scientific Language Literature and Teaching, 6(1), 49-61. https://doi.org/10.22219/kembara.v6i1.11353.

Putri, Q. (2021). Desain Buku Cerita Anak Berbasis Nilai Kearifan Lokal Untuk Pembelajaran Teks Fiksi Siswa Kelas IV Sekolah Dasar. Caruban: Jurnal Ilmiah Ilmu Pendidikan Dasar, 4(1), 20. https://doi.org/10.33603/cjiipd.v4i1.4812.

Rachmah, D. N. (2014). Empati Pada Pelaku Bullying Empathy At The Bullies. Jurnal Ecopsy, 1(2), 51-58. https://doi.org/10.20527/ecopsy.v1i2.487.

Rahmadianti, N. (2020). Pemahaman Orang Tua Mengenai Urgensi Bermain Dalam Meningkatkan 
Perkembangan Sosial Anak Usia Dini. Early Childhood: Jurnal Pendidikan, 4(1), 57-64. https://doi.org/10.35568/earlychildhood.v4i1.717.

Rahmawati, A. (2015). Metode Bermain Peran dan Alat Permainan Edukatif untuk Meningkatkan Empati Anak Usia Dini. In Jurnal Pendidikan Anak (Vol. 3, Issue 1). https://doi.org/10.21831/jpa.v3i1.2875.

Ratnasari, E. M. (2019). Pengaruh Penggunaan Buku Cerita Bergambar Terhadap Kemampuan Berbicara Anak. Scholaria: Jurnal Pendidikan Dan Kebudayaan, 9(3), 267-275. https://doi.org/10.24246/j.js.2019.v9.i3.p267-275.

Rosvita, A. (2021). Pengembangan Media Pembelajaran Buku Cerita Bergambar Berbasis Kemampuan Membaca Pada Pembelajaran Tematik. Jurnal Pendidikan Rokania, VI(1), 23-34. https://doi.org/10.37728/jpr.v6i1.368.

Rosyadi, A. A. P. (2020). Development of Interactive Mathematic Stories (BuCIM) Based on Dienes Theory. Math Didactic: Jurnal Pendidikan Matematika, 6(2), 235-243. https://doi.org/10.33654/math.v6i2.678.

Setiantono, T. (2012). Penggunaan Metode Bercerita Bagi Anak Usia Dini Di PAUD Smart Little Cilame Indah Bandung. Jurnal EMPOWERMENT, 18-23. https://doi.org/10.22460/empowerment.v1i2p18-23.611.

Suartama, I. K. (2016). Evaluasi dan Kriteria Kualitas Multimedia Pembelajaran. Universitas Pendidikan Ganesha.

Sugiyono. (2016). Metode Penelitian Kuantitatif dan Kualitatif dan R\&D. PT Alfabeta.

Sugiyono. (2019). Metode Penelitian Pendidikan (Kuantitatif, Kualitatif, Kombinasi, R\&D dan Penelitian Pendidiakan). Alfabeta.

Surachman, D. (2020). Efektifitasnya Untuk Meningkatkan Hasil Belajar Bahasa Indonesia Siswa Sekolah Dasar. Jurnal Gema Wiralodra, $180-189$. https://doi.org/10.31943/gemawiralodra.v11i2.99.

Suryaningsih, E., \& Fatmawati, L. (2018). Pengembangan Buku Cerita Bergambar Tentang Mitigasi Bencana Erupsi Gunung Api Untuk Siswa SD. Profesi Pendidikan Dasar, 1(2), 110. https://doi.org/10.23917/ppd.v1i2.5310.

Sutanti, T. (2015). Meningkatkan Empati Mahasiswa Prodi BK. Jurnal Psikologi Pendidikan \& Konseling, 1(2), 188-198. https://doi.org/10.26858

Syafitri, S. M. (2020). Menumbuhkan Empati Dan Perilaku Prososial Terhadap Anak Usia Dini Dalam Menanggapi Pelajaran Isu Dunia Nyata. Jurnal Visi Ilmu Pendidikan, 12(2), 140. https://doi.org/10.26418/jvip.v12i2.34049.

Tarigan, N. T. (2019). Pengembangan Buku Cerita Bergambar Untuk Meningkatkan Minat Baca Siswa Kelas IV Sekolah Dasar. Jurnal Curere, 02(02), 141-152. https://doi.org/10.36764/jc.v2i2.157.

Tarini, N. M. W. S. (2018). Pengaruh Metode Bercerita Menggunakan Cerita Rakyat Terhadap Perilaku Empati Anak Kelompok B. E-Journal Pendidikan Anak Usia Dini Universitas Pendidikan Ganesha, 6(1), 11-20. https://doi.org/10.23887/paud.v6i1.15044.

Tegeh. (2014). Model Penelitian Pengembangan. Jurusan Teknologi Pendidikan Fakultas Ilmu Pendidiakn Universitas Pendidikan Ganesha.

Vindaswari, R. F. (2018). Pengembangan Buku Cerita Anak Bergambar Berbasis Nilai-Nilai Kepedulian Bagi Peserta Didik Kelas 2 Sekolah Dasar. Jurnal Fundadikdas (Fundamental Pendidikan Dasar), 1(3), 148. https://doi.org/10.12928/fundadikdas.v1i3.661.

Wicaksono, G. (2020). Pengembangan Buku Cerita Bergambar Interaktif Terhadap Kemampuan Siswa Menemukan Isi Cerita. Joyful Learning Journal, 9(4), 224-229. https: //doi.org/10.15294/jlj.v9i4.40868. 